\title{
LCE analysis of buildings - Taking the step towards Net Zero Energy Buildings
}

\section{A technical report of subtask $A$}

Date: May 26, 2013

By Björn Berggren ${ }^{1, *}$ and Monika Hall ${ }^{2}$

${ }^{1}$ Lund University, Department of Architecture and Built Environment, Division of Energy and Building Design, Box 118, 22100 Lund, Sweden

Telephone: +46462227356

Fax: $\quad+46462224719$

E-mail: bjorn.berggren@ebd.Ith.se

${ }^{2}$ University of Applied Sciences and Arts Northwestern Switzerland, School of Architecture, Civil Engineering and Geomatics, Institute of Energy in Building, St. Jakobs-Strasse 84, CH-4132 Muttenz, Switzerland

Telephone: $\quad+41614674561$

Fax: $\quad+41614674543$

E-mail: $\quad$ monika.hall@fhnw.ch 
This is an author produced version of a paper published in Energy and Buildings This paper has been peer-reviewed but does not include the final publisher proof-corrections or journal pagination.

Citation for the published paper:

Authors: B. Berggren, M. Hall, M. Wall

Title: LCE analysis of buildings - Taking the step towards Net Zero Energy Buildings Journal: Energy and Buildings 62 (2013) 381-391

Doi: http://dx.doi.org/10.1016/j.enbuild.2013.02.063

Access to the published version may require subscription 


\section{Contents}

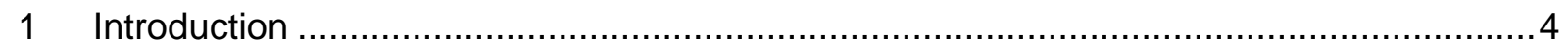

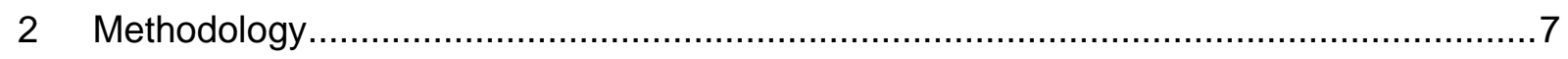

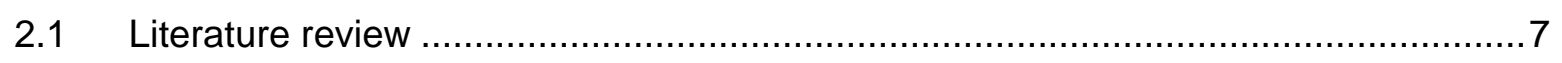

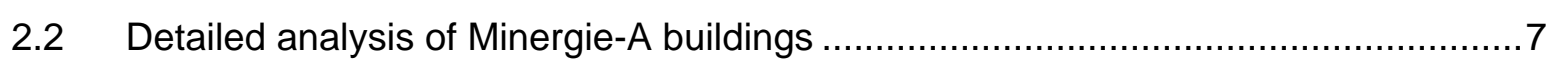

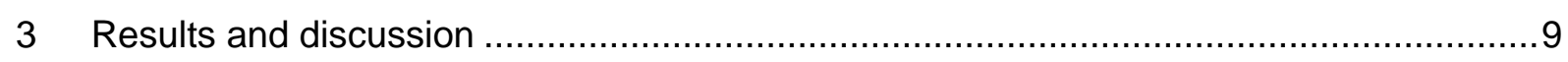

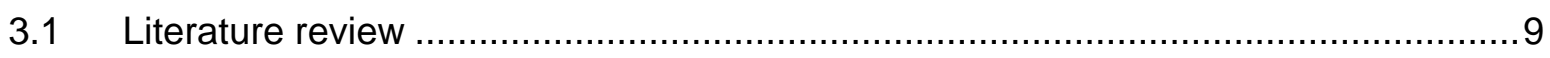

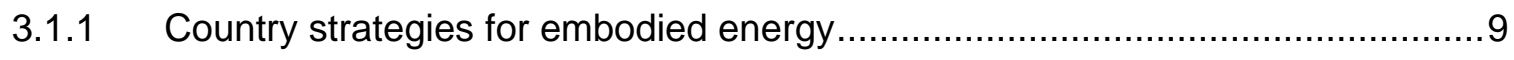

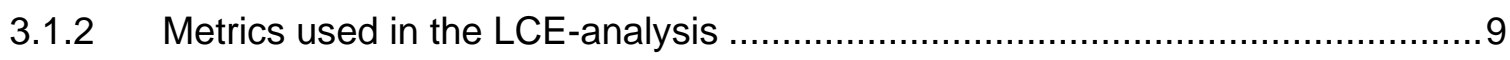

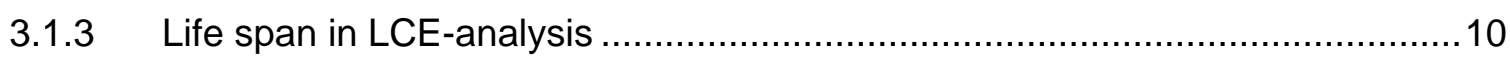

3.1.4 Boundary conditions for the LCE-analysis .............................................. 10

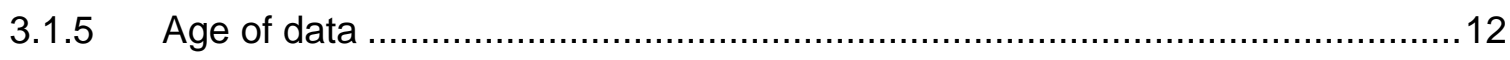

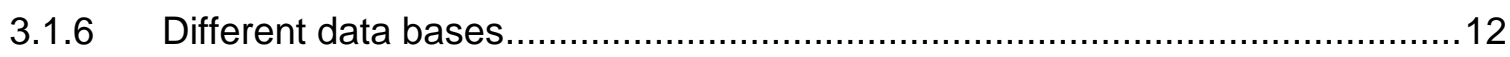

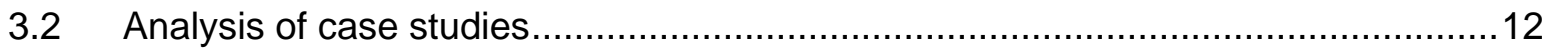

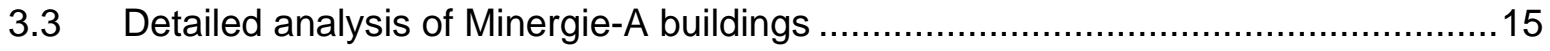

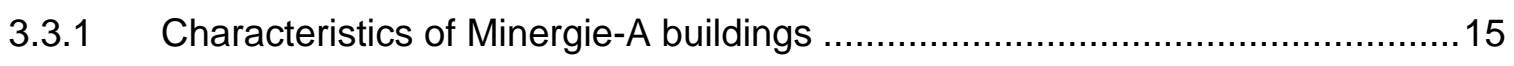

3.3.2 Energy Payback Time and Net Energy Ratio ............................................ 16

3.3.3 Distribution of embodied energy in Minergie-A projects ................................ 18

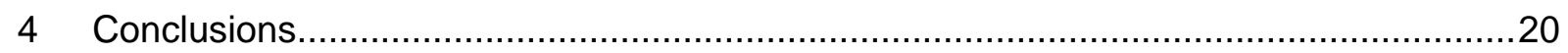

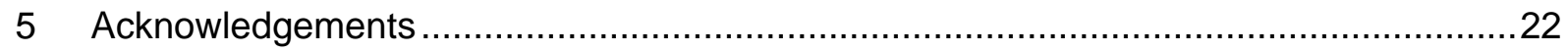

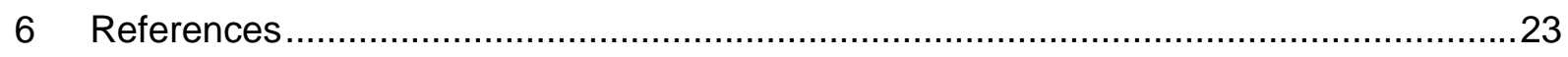

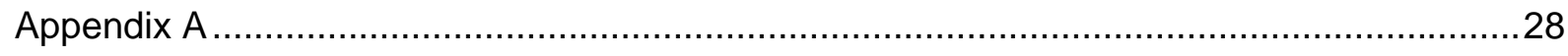

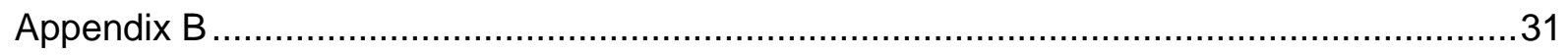




\section{Introduction}

Today a number of buildings exist for which the design principle has been to achieve a Zero Energy Building (ZEB) or Net Zero Energy Building (Net ZEB) [1-6].

There are many different approaches and definitions of the two concepts. In general, the ZEB concept may be described as an autonomous building which does not interact with any external energy supply system (grid) such as district heating network, gas pipe network, electricity grid or likewise. The Net ZEB concept is a building where the weighted supply of energy from the building meets or exceeds the weighted demand and interacts with an energy supply system (grid). Such a building can export energy when the building's system generates a surplus and import energy when the building's system is insufficient to generate the energy required. The scope of the energy balance for the Net ZEB may vary for different concepts but is usually based on an annual balance of primary energy [7]. It is not always clear, however, whether this refers to total primary energy or non-renewable primary energy. Within this paper, the term; "primary energy use" is used when it is not clear whether the source refers to total primary energy use or non-renewable primary energy use.

This paper focuses on Net ZEBs. In Net ZEB definitions, there may or may not be a maximum limit on energy demand. The requirements are generally that the demand is covered by renewable energy sources and that the building is in compliance with the national standards and regulations. However, to meet the goal, a low demand gives an advantage. The general approach to reach Net ZEB could be described as a two-step concept. The first step is to reduce the energy demand by applying energy efficiency measures. The second step is to supply energy, generated by renewable sources, which may be supplied into an external grid when favourable [8-11]. This is illustrated in Fig 1.

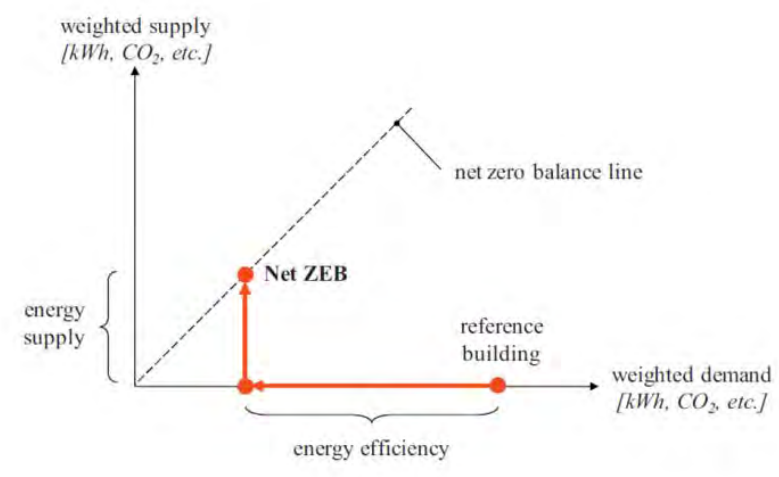

Fig. I Schematic presentation of demand/supply balance of a Net ZEB [1 11$]$

Reduction of energy demand has been promoted worldwide for some time and the techniques used have been applied in Passive Houses and low energy houses for many years and are adapted in the most known Net ZEBs [12]. The basic principle in heating dominated climates may be summarized as design and construction of a well insulated and airtight building envelope in combination with balanced ventilation with high heat recovery efficiency [13-15].

When the energy use of a building is discussed from a lifecycle perspective, it is today generally alleged that energy use in the operational phase of buildings accounts for $70-90 \%$ of energy used during its life cycle. There are a number of substantiated and extensive studies with results supporting that allegation [16-20]. Those studies differ in regard to calculation methodology used to account for the total energy use, Life Cycle Energy (LCE), 
but they reach similar conclusions which support the statement above. However, the consequence is that for Net ZEBs the relative share of energy use related to building operation will decrease.

Earlier studies have mainly focused on embodied energy in buildings with energy performance more or less equal to national building regulations or low energy buildings. An Italian study [21] compared a standard house and a low energy house, clearly showing the changing role of embodied energy in relative terms. The non-renewable primary energy use for construction and maintenance increased by $20 \%$ when taking the step from the standard house to a low energy house. However, the relative share of embodied energy of the total life cycle energy use increased from $17 \%$ to roughly $50 \%$.

Sceptics to the Net ZEB concept might even argue that the energy savings achieved related to building operation of a Net ZEB is lower compared to the increased energy use for production, maintenance and demolition. A German study [22] compared different concepts for a building; built according to building regulations, low-energy house, Passive House and ZEB for a lifespan of 80 years. In general, the life cycle energy use decreased for each step taken towards the Passive House standard. Taking the step to the ZEB, the life cycle energy use increased. The life cycle energy use of a ZEB consists of embodied energy only. Due to the very high technical level of the ZEB, mainly due to the need of large energy storage system, the life cycle energy use of a ZEB is higher compared to a Passive House.

It may be argued that the German study is inconsistent since the life cycle energy use for the ZEB includes all embodied energy for the building's on-site generation and energy storage systems, whereas the embodied energy of the grid supplying the Passive House with energy is not included in the life cycle energy balance comparison.

The main purpose of the study presented in this paper is to analyse the embodied energy where the focus is on the impact on the total life cycle energy use when the step is taken from a low energy building to Net ZEB instead of ZEB and to highlight important parameters that the authors believe should be addressed in the context of a life cycle energy analysis.

Life cycle energy analysis is one way of conducting Life Cycle Assessment (LCA). Other ways to assess the environmental impact of buildings may be to calculate the carbon footprint or Life Cycle $\mathrm{CO}_{2}\left(\mathrm{LC} \mathrm{CO}_{2}\right)$. Some studies combine the evaluation of life cycle energy use with calculation of global warming potential, ozone emissions, carbon foot print, etc. $[21,23,24]$. The relative impact of different measures will change when applying different methodologies. Especially, this can be seen in $[23,24]$, where the energy analysis is not based on primary energy. Analysing conversion factors for $\mathrm{CO}_{2}$-equivalents and primary energy, presented in [11], the ratios are more alike when comparing factors for nonrenewable primary energy and $\mathrm{CO}_{2}$-equivalents than compared to ratios between factors for total primary energy and $\mathrm{CO}_{2}$-equivalents. However, differences still occur; comparing ratios for non-renewable primary energy and $\mathrm{CO}_{2}$-equivalents. For example, non-renewable primary energy factors for oil and natural gas are roughly the same, whereas the factors for $\mathrm{CO}_{2}$-equivalents for oil are roughly $20 \%$ higher compared to natural gas. In this study, the metric; non-renewable primary energy is in focus. This is due to that data from previous studies generally were given as primary energy. Specifically, non-renewable primary energy was chosen to better reflect the environmental impact in form of $\mathrm{CO}_{2}$-equivalents.

Table 1 shows a list of nomenclature used in this paper. 


\section{Table 1 Nomenclature used in this paper}

\section{ZEB Zero energy building, autonomous building}

Net ZEB Net zero energy building, all energy as defined in EN 15603 [25] included

Net ZEB $\quad$ Net zero energy building, limited balance; energy for lighting and other services are excluded

LCE Life cycle energy

LCA Life cycle analysis

EE $\quad$ Embodied energy $\left(E E=E_{i}+E_{r}+D E\right)$

$\mathrm{EE}_{i} \quad$ Initial embodied energy

$\mathrm{EE}_{r} \quad$ Recurring embodied energy

DE Demolition energy

OE Operating energy. Net energy use related to building operation

HP Heat pump

PV Photovoltaic

ST Solar thermal

EPR Energy payback ratio

EPT Energy payback time

NER Net energy ratio 


\section{Methodology}

\subsection{Literature review}

The literature review was conducted by reviewing peer-reviewed papers and through a survey among participating researchers of the IEA SHC Task40/ECBCS Annex52 "Towards Net Zero Energy Solar Buildings", asking for case studies where LCE analyses were conducted and for information on country specific strategies for LCE analysis.

The purpose of the literature review was threefold;

- Identifying parameters which were handled differently in the studies

- Studying different databases, tools and rating systems used today

- Gathering LCE analysis data to enable analysis of the embodied energy as a relative share of life cycle energy use and the changing role of embodied energy.

All data were normalized into $\mathrm{kWh} /\left(\mathrm{m}^{2} \mathrm{a}\right)$. Only data based on primary energy were used, and where all energy use related to building operation was included in the operating energy (OE). However, primary energy factors used were not always presented and it was not always clear whether the data were in total primary energy or non-renewable primary energy. Furthermore, it was not always clearly stated what parts of the energy use were included in operating energy.

\subsection{Detailed analysis of Minergie-A buildings}

The Minergie ${ }^{\circledR}$ concept was developed in 1994 and since 1998 the Minergie ${ }^{\circledR}$ association has worked continuously to define and promote energy efficient buildings [26]. The Minergie institute has defined three different labels/definitions of energy efficient buildings where Minergie-A [27] is the latest standard for residential buildings, implemented in 2011. A Minergie-A building has a heating demand $\leq 90 \%$ of the allowed heating demand according to the Swiss building regulations [28]. Also, a net zero energy balance for space heating, domestic hot water and ventilation is required, based on weighted energy carriers defined in [27]. If the energy carrier for heating is wood and more than $50 \%$ of the space heating and domestic hot water is covered by solar thermal collectors, a credit of $15 \mathrm{kWh} /\left(\mathrm{m}^{2} \mathrm{a}\right)$, weighted energy, is given. It is required to calculate embodied energy, which must not exceed 50 $\mathrm{kWh} /\left(\mathrm{m}^{2} \mathrm{a}\right)$, non-renewable primary energy. Energy efficient white goods are required.

Minergie-A buildings are appropriate examples to evaluate the step towards Net ZEBs. They are Net $Z E B_{L}$ balanced, e.g. energy for plug loads and lighting is not included in the requirements.

In this study, the embodied energy of Minergie-A buildings includes the superstructure, building envelope and the HVAC system. The calculation of embodied energy was carried out based on data from the Bauteilkatalog [29]. Embodied energy data within Bauteilkatalog includes energy for replacement when the expected service life time expires and energy for demolition is included (cradle to grave analysis). Hence, the total life cycle energy use is analysed.

Further analysis focused on studying the effect on embodied energy and operating energy due to photovoltaic panels (PV panels), and solar thermal collectors. All buildings were redesigned and recalculated to examine the effect of taking the step towards Net ZEB, using a three-step approach:

- Buildings' redesigned and recalculated without PV panels (Low energy standard).

- Buildings' redesigned and recalculated with enough PV panels to meet a Net ZEBL balance.

- Buildings' redesigned and recalculated with enough PV panels to meet a Net ZEB balance. 
When data was extracted from the data base (July 2011) [30], a total of 11 buildings had applied for Minergie-A certification. For this study, all data for the Minergie-A buildings were recalculated with Swiss weighting factors for non-renewable primary from SIA 2031 [31], Table 2.

Table 2 Swiss weighting factors for non-renewable primary energy [31]

\begin{tabular}{lc}
\hline Energy carrier & Weighting factor, non-renewable primary energy $[-]$ \\
\hline Electricity & 2.52 \\
Wood & 0.05 \\
Pellets & 0.21 \\
District heating & 0.79 \\
Oil & 1.23 \\
Natural gas & 1.14 \\
\hline
\end{tabular}

Operating energy use for plug loads and lighting are not included in the Minergie ${ }^{\circledR}$ calculations. To enable analysis including the total operating energy, energy for lighting and plug loads was included in the energy demand. This results in an additional OE of 51.7 $\mathrm{kWh} /\left(\mathrm{m}^{2} \mathrm{a}\right)$, non-renewable primary energy. This estimation is based on a mean value of 20.5 $\mathrm{kWh} /\left(\mathrm{m}^{2} \mathrm{a}\right)$ of delivered electricity, measured for plug loads and lighting in 16 Passive House dwellings in Sweden [15]. 


\section{Results and discussion}

\subsection{Literature review}

Within the literature review, a total of 143 case studies were collected [19-20, 32-45]. Out of these cases studies, 73 cases were summarized in tabular form in [20]; clearly showing the embodied energy, operating energy and life cycle energy use. A summary of the data for the additional 70 cases is presented in Appendix $A$, following the same principle to enable comparison. Furthermore 11 case studies were gathered from the Minergie-A database [30], making a total of 154 cases available for analysis.

The basic framework for calculation of life cycle energy (LCE) use was defined differently in different studies. The overall goal, however, was to calculate the sum of all energies incurred in the life cycle of the studied project and/or building. The life cycle energy use may be defined as in Equation 1 according to Ramesh et al [20] or as graphically described by Dixit et al [46]. Comparing the two, one can see that the overall framework is the same.

$$
\mathrm{LCE}=\mathrm{EE}_{i}+\mathrm{OE}+\mathrm{EE}_{r}+\mathrm{DE}
$$

where LCE is the total life cycle energy use, $\mathrm{EE}_{i}$ is the initial embodied energy, OE is the operating energy, $E_{r}$ is the recurring embodied energy and $D E$ is the demolition energy.

\subsubsection{Country strategies for embodied energy}

Today, no country has requirements regarding embodied energy requirement for buildings. Some countries have developed non-mandatory standards [47-49] that could be incorporated as a baseline in a building rating system. Many rating systems enable a possibility to include the environmental impact of building materials in the assessment of a building's environmental impact [26,50-58]. However, only two of twelve Net ZEB definitions reviewed in [7] consider including embodied energy in the Net ZEB balance.

A common barrier for all countries is the lack of a national matured and agreed database for building materials. Within Europe, there are two commonly used, extensive databases; Ecoinvent [59] and GEMIS [60]. However, other databases exist, e.g. [61-65], and a lot of different tools are available to calculate embodied energy, global warming potential, impact of the environment and other parameters for construction materials and assemblies, e.g. [29, 66-68].

On a European transnational level, an European Ecolabel and Green Public Procurement (GPP) criteria for buildings is being developed [69]. Within the European Commission, the Joint Research Centre, a web based platform has been developed where guidelines, tools and life cycle data are published [70].

\subsubsection{Metrics used in the LCE-analysis}

To ensure transparency and consistency, the applied metric for LCE analysis should be primary energy. Dixit et al. [46] concludes that inclusion of delivered energy in LCE analysis creates complications.

Delivered energy may also be referred to as final, end-use or un-weighted energy [7]. 
Within [19] 45 of 60 cases are presenting operating in primary energy. It is however not always clear whether the term primary energy refers to total primary energy or nonrenewable primary energy.

As mentioned in the introduction, some studies combine the evaluation of life cycle energy use with calculation of global warming potential, ozone emissions etc. These types of analyses together with LCE analysis are different types of Life Cycle Assessments (LCAs). The difference between LCA and LCE analysis is that within LCA many different indicators may be used in the evaluation. In LCE, the indicator is always energy. The calculated life cycle energy use is usually divided by an assumed life-span of the building and the conditioned area. Hence the indicator is given in $\mathrm{kWh} /\left(\mathrm{m}^{2} \mathrm{a}\right)$.

\subsubsection{Life span in LCE-analysis}

When the result from the LCE analysis is presented in $\mathrm{kWh} /\left(\mathrm{m}^{2} \mathrm{a}\right)$, the expected life-span has no impact on the analysis of operating energy, in absolute terms, if the analysis is based on a simulation of the annual energy use and assumes that the energy supply system, extraction of raw materials for energy generation etc. do not change over time. However, it may have a significant impact on initial embodied energy and demolition energy as this is based on activities that occur once (energy for replacement, recurring embodied energy, may occur more or less than one time) and the energy use is divided by the assumed life-span.

The life-span used in the different studies varies between 30 and 100 years. Out of the 154 different cases, the average life-span is 53 years and the median is 50 years. In Fig. 2, the allocation of the different case studies is shown; the most used life-span is 50 years.

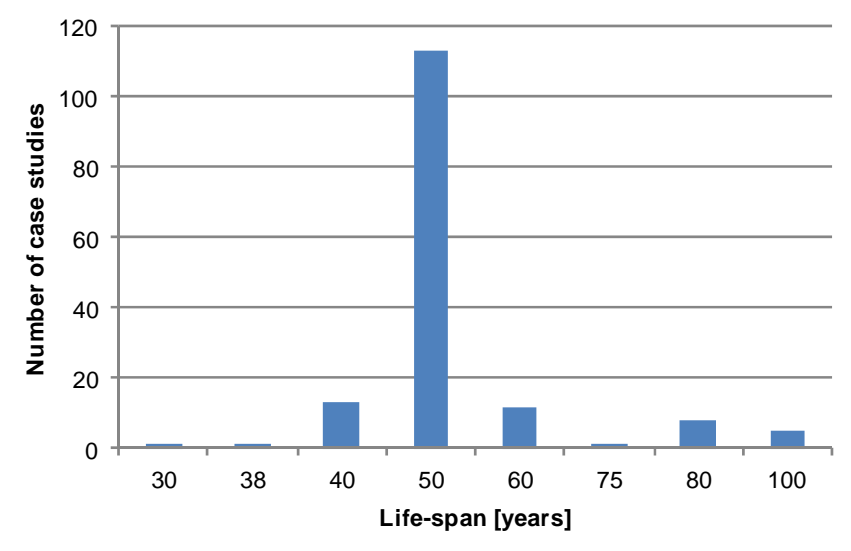

Fig. 2 Allocation of different case studies based on the applied life-span in the 154 different case $\underline{\text { studies. }}$

\subsubsection{Boundary conditions for the LCE-analysis}

A common problem in LCE analysis is to acquire all data coupled to the life cycle. The system boundary may be set where the data collection is getting too difficult and may therefore be strongly related to availability of research resources.

Differences may be found whether demolition, recycling, feed-stock energy and renovation are included. Furthermore, no analysis in the studied material seems to include furnishings. Adalberth [16] and Blengini et al [21] include white goods and sanitary ceramics in addition to materials included in the structural elements, building envelope and HVAC-system. Suzuki et 
al [71] and Cole et al [72] are two examples of studies with focus on the materials included in the structural elements, building envelope and HVAC-system.

Studies sometimes refer to life cycle energy use as the sum of embodied energy and operating energy. This may indicate that demolition energy is excluded in the analysis or included in the embodied energy. E.g. in [73] a LCE analysis is presented, excluding demolition energy. In [74] life cycle energy use refers to the sum of embodied energy and operating energy, including demolition energy in the embodied energy. However, the effect of energy use during demolition is often small. In [16] the relative share of energy use due to demolition was $<1 \%$ of the total life cycle energy use. In $[17,21,75]$ the energy use during demolition was negative, i.e. the energy extracted from the materials through recycling and combustion exceeded energy needed for disassembly. Hence, differences between different studies due to including or excluding demolition energy may be expected to be small.

Based on differences in the reviewed studies it is possible to divide the boundary conditions into two main categories:

- Boundary conditions regarding downstream and upstream processes

- Boundary conditions regarding material included in the analysis

To address the second category and to enhance transparency in the LCE-analysis, one may separately analyze the embodied energy of a measure taken to improve the operating energy use of a building. This approach is based on a marginal utility approach and assumes that the building or buildings that are analyzed is/are to be built anyway. It is therefore sufficient to analyze the specific effect of different measures in relation to a reference case in order to find good measures from a LCE perspective. This may be implemented in different ways.

Leckner et al [45] use two different indices in LCE-analysis; Energy Payback Ratio, EPR, and Energy Payback Time, EPT. The indices are described in Equation 2 and Equation 3.

Hernadez et al [76] suggest the use of a similar index as EPR called Net Energy Ratio, NER. The difference between the two indices is that EPR is based on the total changes over the life cycle and NER is based on the annual change, Equation 4. If the operating energy use is based on a simulation of the energy demand and assumes that the energy supply system, extraction of raw materials for production of energy etc. do not change over time, EPR and NER will have the same quota. The NER may also be referred to as Energy Yield Ratio or Energy Return of Investment.

$$
\mathrm{EPR}=\Delta \mathrm{OE}_{T} / \Delta \mathrm{EE}_{T}
$$

where EPR is the energy payback ratio for a specific measure, $\Delta O E_{T}$ is the total life cycle difference of operating energy due to the specific measure and $\Delta \mathrm{EE}_{T}$ is the total difference of embodied energy due to the specific measure.

$$
\mathrm{EPT}=\Delta \mathrm{EE}_{T} / \Delta \mathrm{OE}
$$


where EPT is energy payback time for a specific measure and $\triangle \mathrm{OE}$ is the annual difference of operating energy due to the specific measure.

$$
\mathrm{NER}=\Delta \mathrm{OE} / \triangle \mathrm{EE}
$$

where NER is the net energy ratio for a specific measure and $\triangle E E$ is the annual difference of embodied energy due to the specific measure.

\subsubsection{Age of data}

Energy use means capital expenditures. Therefore, in the production and distribution of materials and components the industry is always looking for cost-efficient ways to streamline and decrease the energy use. As a natural consequence, age of data has a large impact on the result of an analysis. A good example of where the market has decreased costs and decreased energy use is the production of Crystalline Silicon PV modules. In [77] the overlap between price and energy pay-back time of Crystalline Silicon PV modules were presented. The study showed that the EPT of PV modules decreased from 20 years, in the 1970s, to below five years, in 2005.

\subsubsection{Different data bases}

As mentioned in Section 3.1.1, a number of tools and databases that can be used to compile and analyze embodied energy for buildings are available today. Dixit et al [46] highlight and discuss the source of data as an important parameter that influences the result in embodied energy analysis.

Villa et al [44] present five case studies in which three different databases have been used (Case studies 43-58 in Appendix A, Table A.2). A comparison of the results of calculated embodied energy show a percentage difference of $15 \%-87 \%$ for the different case studies due to use of different databases. The authors conclude that an important contributing factor to the differences is different methods used to quantify embodied energy for wooden products in databases used in their analysis.

The differences in the data bases are in general due to the above-named parameters and due to specific conditions regarding energy-mix, fabrication methods and transportation.

\subsection{Analysis of case studies}

Results given in this section are based on all 154 cases studies.

In Fig. 3 the relationship between operating energy and life cycle energy is presented for all cases from the literature review together with data from Minergie-A buildings [20, 30, 32-45]. In Fig. 4, case studies with operating energy $>100 \mathrm{kWh} /\left(\mathrm{m}^{2} \mathrm{a}\right)$ are excluded. The relationship between operating energy and life cycle energy is almost linear. This data correspond well with the earlier, highlighted, linear relationship in $[19,20]$. The negative values of operating energy occur if the energy supply exceeds the energy demand. 


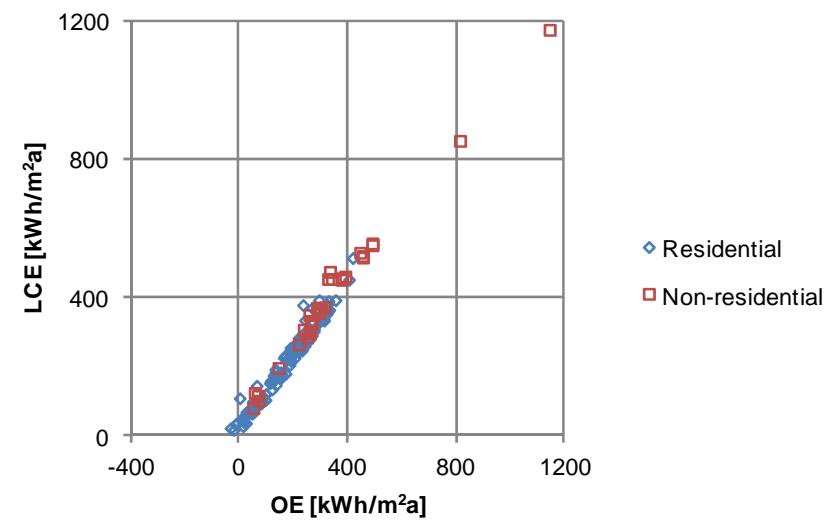

Fig. 3 Relationship between operating energy (OE) and life cycle energy (LCE), primary energy. All 154 case studies are included.

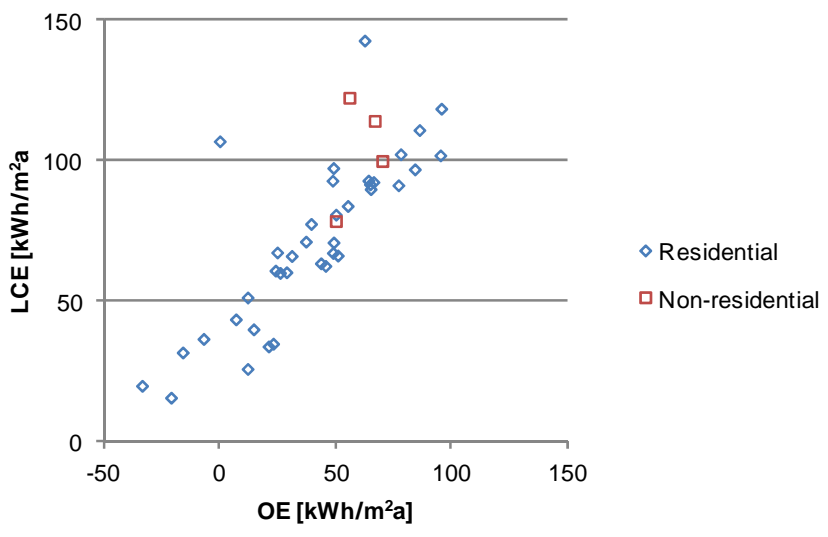

Fig. 4 Relationship between operating energy (OE) and life cycle energy (LCE), primary energy. Case studies with $\mathrm{OE}<100 \mathrm{kWh} /\left(\mathrm{m}^{2} \mathrm{a}\right)$.

Low energy buildings and Net ZEBs usually requires more material in form of insulation and installations (PV panels, solar thermal collectors, heat pumps etc.). Hence it could be logical to assume that the linear relationship between operating energy and life cycle energy would flatten out. However the tendency is that the linear relationship is constant. This may be due to that design and construction often has a focus on sustainable material management. Furthermore, PV panels and solar thermal collectors generate more energy during building operation, compared to the embodied energy. It may also be partly due to that newer buildings show a tendency of a lower embodied energy compared to older buildings, see Fig. 5. The decrease could be due to more efficient use of materials and more efficient manufacturing. 


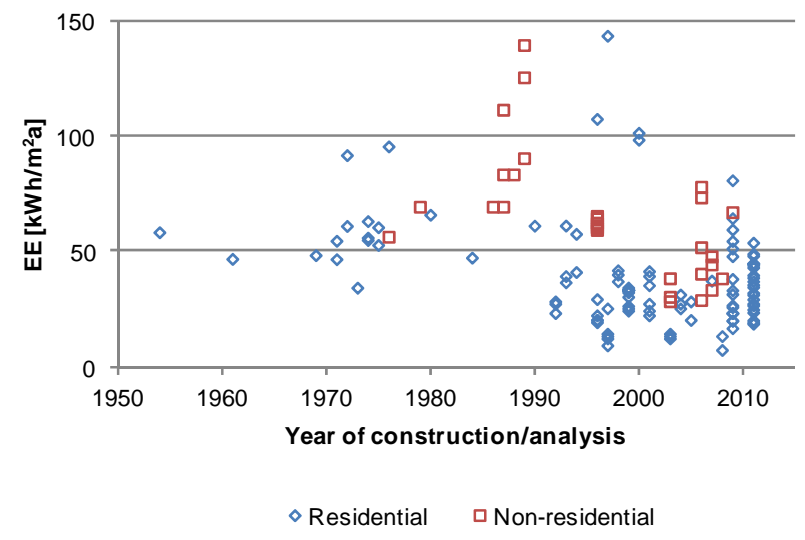

Fig. 5 Embodied energy (primary energy) by year of construction.

In Fig. 6 and Fig. 7 the relationship between the operating energy and the embodied energy as percentage share of life cycle energy use is presented together with an exponential regression for residential buildings and non-residential buildings. As there are no case studies for non-residential buildings where operating energy $\leq 0 \mathrm{kWh} /\left(\mathrm{m}^{2} \mathrm{a}\right)$, data for a fictitious building have been incorporated.

Using the exponential regression formulas, the embodied energy exceeds $50 \%$ of life cycle energy use when the annual operating energy use is $\geq 33 \mathrm{kWh} /\left(\mathrm{m}^{2} \mathrm{a}\right)$ and $\geq 45 \mathrm{kWh} /\left(\mathrm{m}^{2} \mathrm{a}\right)$ for residential and non-residential buildings respectively. It may occur as strange that embodied energy as a share of life cycle energy exceeds $100 \%$ when the operating energy $<0$ $\mathrm{kWh} /\left(\mathrm{m}^{2} \mathrm{a}\right)$. The effect is due to buildings that annually supply more energy than the annual energy demand, every year generating a surplus and thus reducing the total life cycle energy use.

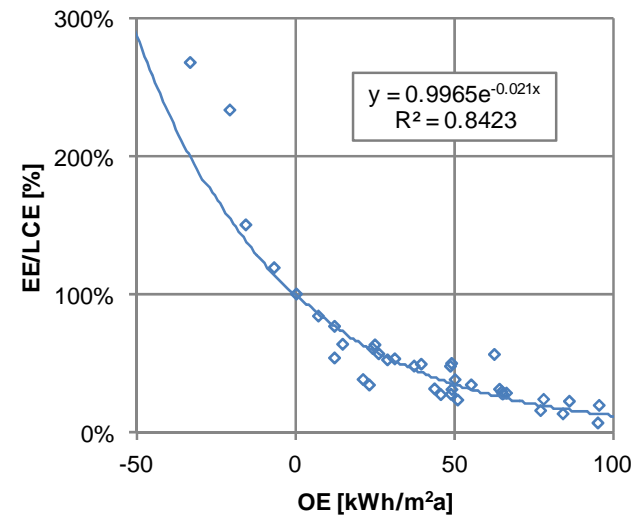

$\bullet$ Residential

Fig. 6 Relationship between OE and EE/LCE (primary energy) for residential case studies with $\mathrm{OE}<100 \mathrm{kWh} /\left(\mathrm{m}^{2} \mathrm{a}\right)$. 


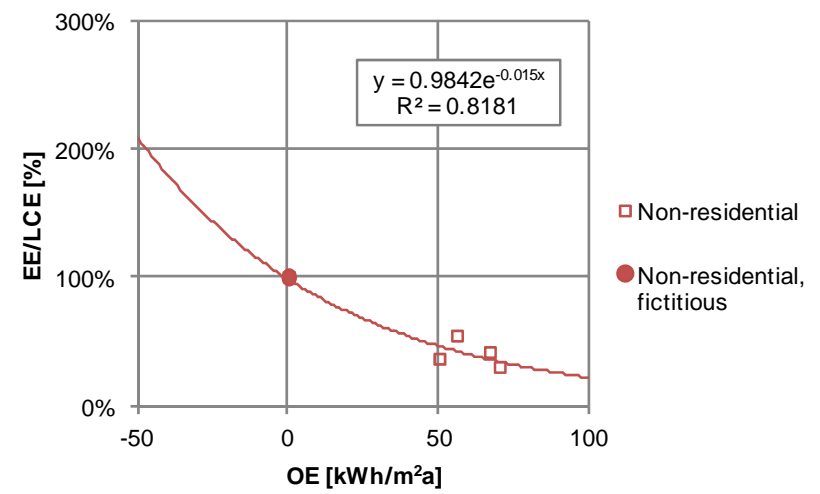

Fig. 7 Relationship between OE and EE/LCE (primary energy) for non-residential case studies with

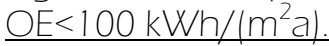

\subsection{Detailed analysis of Minergie-A buildings}

\subsubsection{Characteristics of Minergie-A buildings}

A summary of the gathered data from the Minergie-A database is presented in Table 3. All cases are residential buildings. Three stakeholders outperform the Minergie-A requirement of Net ZEB $\mathrm{L}_{\mathrm{L}}$ balance, with the goal to reach Net ZEB balance (Case studies $71,74 \& 77$ ).

All case studies have installed PV panels. Except no 76, all buildings have applied energy efficiency measures similar to a Passive House design with advanced thermal insulation and ventilation with heat recovery. Buildings without heat pump (HP), have installed pellet-/wood boiler. None of the Net ZEB buildings have installed heat pump.

Table 3 Summary of characteristics for Minergie-A buildings [30]

\begin{tabular}{rrrrrr}
\hline $\begin{array}{l}\text { Case } \\
\text { study }\end{array}$ & $\begin{array}{l}\text { Gross area } \\
{\left[\mathrm{m}^{2}\right]}\end{array}$ & $\begin{array}{l}\text { Life } \\
\text { span }\end{array}$ & $\begin{array}{l}\mathrm{EE} \\
{\left[\mathrm{kWh} /\left(\mathrm{m}^{2} \mathrm{a}\right)\right]}\end{array}$ & $\begin{array}{l}\mathrm{OE} \\
{\left[\mathrm{kWh} /\left(\mathrm{m}^{2} \mathrm{a}\right)\right]}\end{array}$ & $\begin{array}{l}\mathrm{LCE} \\
{\left[\mathrm{kWh} /\left(\mathrm{m}^{2} \mathrm{a}\right)\right]}\end{array}$ \\
\hline 71 & 374 & 60 & 53 & -33 & 20 \\
72 & 227 & 60 & 32 & 29 & 60 \\
73 & 440 & 60 & 49 & 49 & 98 \\
74 & 290 & 60 & 48 & -16 & 32 \\
75 & 221 & 60 & 43 & 25 & 67 \\
76 & 306 & 60 & 38 & 39 & 78 \\
77 & 249 & 60 & 37 & -21 & 16 \\
78 & 314 & 60 & 34 & 26 & 60 \\
79 & 1206 & 60 & 37 & 7 & 44 \\
80 & 1087 & 60 & 34 & 37 & 93 \\
81 & 1056 & 60 & 44 & 49 & 71 \\
\hline
\end{tabular}


The deviation and mean values of photovoltaic peak power and area of solar thermal collectors (STC) per heated areas based on Table 3 and sorted by the Net ZEB balance concept are shown in Fig. 8. Generally, buildings without a heat pump (HP) have larger solar thermal collectors and PV panels than buildings with heat pump. Also, buildings with Net ZEB balance have larger solar thermal collectors and higher installed nominal power $(\mathrm{kWp})$ for PV panels than buildings with Net $Z E B_{\llcorner}$balance.

In case studies with Net $Z E B_{\llcorner}$balance, installation of a heat pump enables a mean reduction of solar thermal collectors by $50 \%$. Installed nominal power (kWp) for PV panels are roughly the same. None of the Net ZEB balance buildings have heat pump.

Assuming that the buildings are equal to low energy/Passive House standard, taking the step from a low energy house/Passive House to a Net $Z_{E B}$ acquires instalment of $0.019 \mathrm{kWp} \mathrm{PV}$ panels and $0.030 \mathrm{~m}^{2}$ of solar thermal collectors per gross heated floor area. Alternatively; $0.020 \mathrm{kWp}$ for PV panels, $0.015 \mathrm{~m}^{2}$ of solar thermal collectors and a heat pump.

Comparing cases without heat pump; taking the step from Net ZEB $B_{L}$ to Net ZEB acquires a mean increase of $P V$ panels by $0.018 \mathrm{kWp}$ and solar thermal collectors by $0.050 \mathrm{~m}^{2}$ per gross heated floor area. This roughly corresponds to, taking the step from Net ZEB $B_{\mathrm{L}}$ to Net ZEB, a doubled kWp installed for PV panels. The ratio of solar thermal collector area, comparing Net ZEB and Net ZEB , are eight to three.

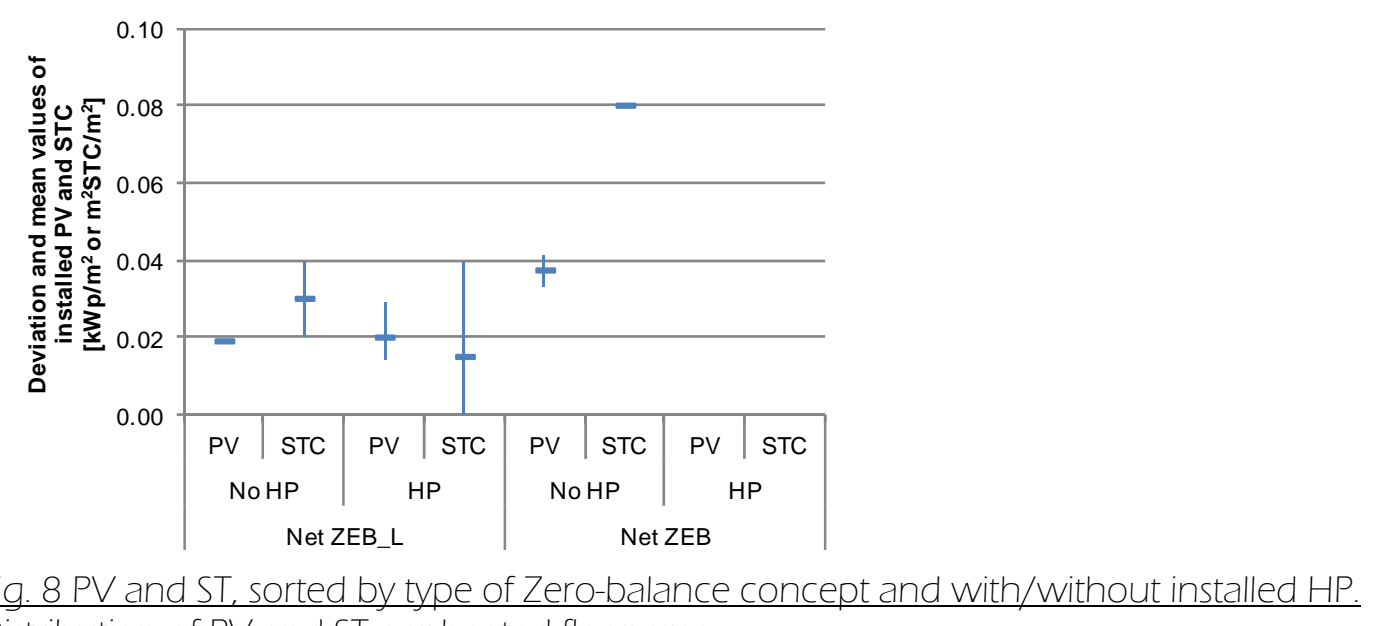

Distribution of PV and ST per heated floor area..

The average installed PV power, $\mathrm{kWp} / \mathrm{m}^{2}$, for Net ZEBs corresponds well with [12], which provides more in-depth analysis of Net ZEB characteristics. More detailed analyses of the characteristics of Net ZEBs may also be found in $[3,4]$.

\subsubsection{Energy Payback Time and Net Energy Ratio}

Energy Payback Time (EPT) and Net Energy Ratio (NER) were calculated according to Equation 3 and Equation 4. In order to calculate EPT and NER, $\triangle \mathrm{OE}$ needs to be calculated. The calculations are based on non-renewable primary energy.

The results differ depending on the energy source replaced. E.g. if solar thermal collectors are replacing $1 \mathrm{kWh}$ of electricity; $\Delta \mathrm{OE}=2.52 \mathrm{kWh}$, replacing $1 \mathrm{kWh}$ of district heating; $\Delta \mathrm{OE}=0.79 \mathrm{kWh}$ etc. 
To compare the different energy supply strategies: district heating, electricity, oil or natural gas was compared with the photovoltaic, solar thermal or heat pump systems. The deviation and mean value of EPT and NER for all cases are presented in Table 4. Basis for the calculations is presented in Appendix B.

Heat pumps show by far the lowest EPT, often less than one year. The EPT for PV panels are often ten times higher, and for solar thermal collectors often three times higher. Hence, installing a heat pump is a recommended solution from a LCE perspective.

PV panels have the highest EPT and should therefore be the last option to consider. If, for any reason, the option of installing a heat pump is not chosen; the appropriate design strategy would be to first size and install a solar thermal collector system with respect to the energy needed for heating before considering PV. Furthermore, electricity generated from PV should not be used within the building to replace district heating; instead it should be exported to the grid, in order to replace electricity. However, this design strategy assumes that there is always an energy load in the grid. Furthermore it does not consider possible increased stress on the grid if an export strategy is chosen.

Examining the NER calculations, where high NER is preferable, confirms the recommendations above. However, some differences may be noted. Within the EPT comparison, there was roughly a factor three difference between PV panels and solar thermal collectors. Comparing NER, the difference is reduced; roughly to two. Comparing the heat pumps and solar thermal collectors, the mean factor difference of EPT is 3.8. The mean factor difference of NER is 5.8. The differences occur due to that the NER methodology includes the effect of the expected service life time of a measure. In this case the service life times are 30 years for PV panels and heat pumps, and 20 years for solar thermal collectors.

Table 4 Results from calculations of EPT and NER

\begin{tabular}{|c|c|c|c|c|c|c|c|}
\hline \multirow{2}{*}{$\begin{array}{l}\text { Renewable } \\
\text { energy supply } \\
\text { option }\end{array}$} & \multirow{2}{*}{$\begin{array}{l}\text { Replacing energy } \\
\text { source }\end{array}$} & \multicolumn{3}{|c|}{$\begin{array}{l}\text { Energy payback time } \\
\text { [years] }\end{array}$} & \multicolumn{3}{|c|}{ Net energy ratio [-] } \\
\hline & & Max & Min & Mean & Max & Min & Mean \\
\hline \multirow[t]{4}{*}{ Photovoltaic } & District heating & 13.1 & 10.4 & 11.5 & 2.9 & 2.3 & 2.6 \\
\hline & Electricity & 4.1 & 3.2 & 3.6 & 9.2 & 7.3 & 8.3 \\
\hline & Oil & 7.7 & 6.1 & 6.8 & 5.0 & 3.9 & 4.5 \\
\hline & Natural gas & 8.6 & 6.8 & 7.6 & 4.4 & 3.5 & 4.0 \\
\hline \multirow[t]{4}{*}{ Solar thermal } & District heating & 4.7 & 2.6 & 3.8 & 7.6 & 4.3 & 5.4 \\
\hline & $\begin{array}{l}\text { Electricity for } \\
\text { heating }\end{array}$ & 1.3 & 0.7 & 1.1 & 27.0 & 15.2 & 19.3 \\
\hline & Oil & 2.7 & 1.5 & 2.2 & 13.0 & 7.3 & 9.3 \\
\hline & Natural gas & 3.1 & 1.7 & 2.5 & 11.6 & 6.5 & 8.3 \\
\hline \multirow[t]{4}{*}{ Heat pump } & District heating & 1.3 & 1.0 & 1.1 & 30.1 & 22.2 & 27.6 \\
\hline & $\begin{array}{l}\text { Electricity for } \\
\text { heating }\end{array}$ & 0.4 & 0.3 & 0.3 & 106.6 & 78.8 & 92.8 \\
\hline & Oil & 0.8 & 0.3 & 0.5 & 94.0 & 38.0 & 68.8 \\
\hline & Natural gas & 0.9 & 0.3 & 0.5 & 94.0 & 33.8 & 66.3 \\
\hline
\end{tabular}




\subsubsection{Distribution of embodied energy in Minergie-A projects}

The distribution of embodied energy within the different Minergie-A cases are presented here. The results should be studied in the context that they are based on mid-European climate and primary energy factors for Swiss non-renewable primary energy factors [31].

The deviation of embodied energy in Minergie-A cases is shown in Fig. 9. Roughly $60 \%$ of the embodied energy is due to the structural elements, $20 \%$ for HVAC and $20 \%$ for solar thermal collectors and PV panels. Heavy weight buildings do not necessarily have a higher embodied energy for structural elements. This could be a result of differences in expected life span for light and heavy weight constructions. Light weight walls have an expected life span of 40 years, heavy walls 60 years [29].

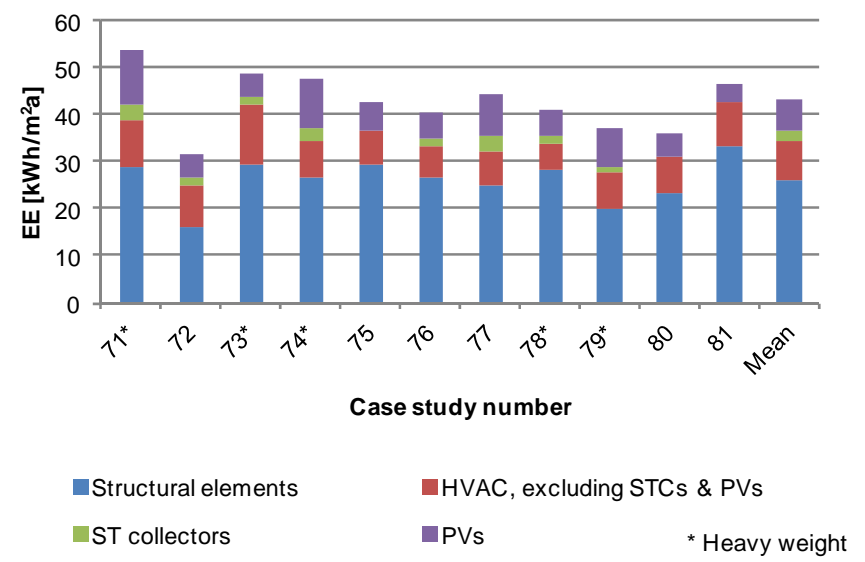

Fig. 9 Embodied energy (EE) within Minergie-A cases (non-renewable primary energy). Cases marked with *; indicates heavy weight superstructure.

The detailed distribution of embodied energy and operating energy use is presented in Fig. 10. For each project, demand and supply related to operating energy and embodied energy is presented. E.g. there is an energy demand to produce PV panels, presented as embodied energy on the demand side in Figure 10 (EE PVs). However, the PV panels also supply energy during building operation, presented as operating energy on the supply side (OE PVs).

Examining the demand for the different cases, the following rough division may be done: 35 $\%$ is embodied energy, $45 \%$ is demand for plug loads and lighting and $20 \%$ is demand for heating, hot water and mechanical systems. The deviation of loads are roughly the same for buildings with Net ZEB $\mathrm{L}_{\mathrm{L}}$ balance and Net ZEB balance. 


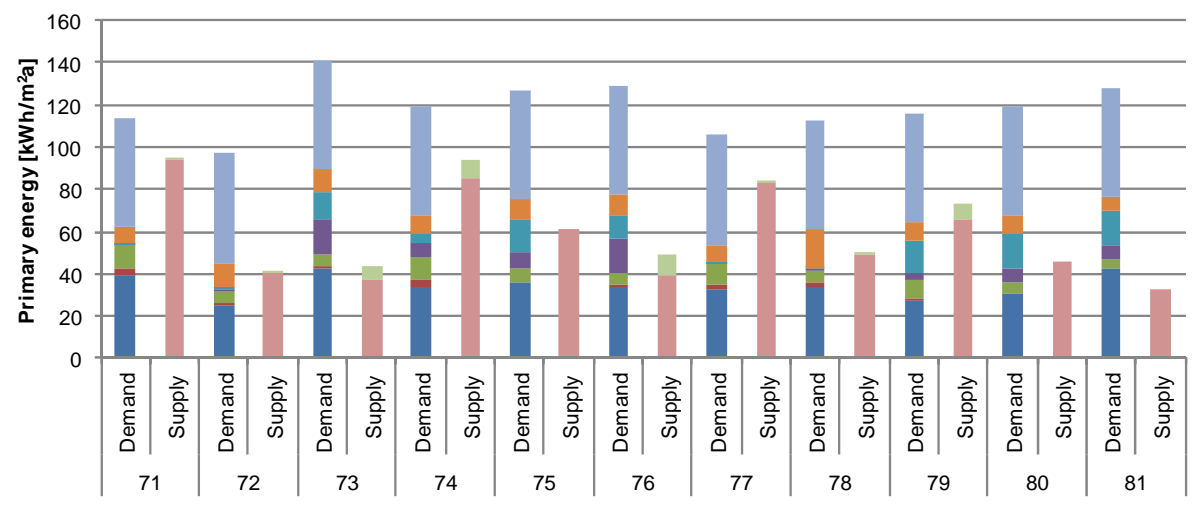

OE STCS

OE PVS

- OE Plug loads + lighting

OE Aux. Electricity

nOE Hot water

aE Heating

-EE PVs

nEE STCS

EE Overall w/o STCs \& PVs

Fig. 10 Distribution of operating energy (OE) and embodied energy (EE) by demand and supply in Minergie-A projects (non-renewable primary energy).

Fig. 11 shows mean values of operating energy use and embodied energy for the three different building standards based on the 11 Minergie-A cases, recalculated as stated in chapter 2.2. Also the variation of the total life cycle energy use is presented.

The results show that the increase of embodied energy does not negatively affect the step from a low energy building towards a Net ZEB. When taking the step from a low energy building to a Net ZEB, the increase of embodied energy is about $25 \%$. However, the operating energy use drops down to zero. The life cycle energy use of a Net ZEB is calculated to be about $40 \%$ of the life cycle energy use a low energy building. The life cycle energy use of a Net ZEB is much lower compared to a low energy building.

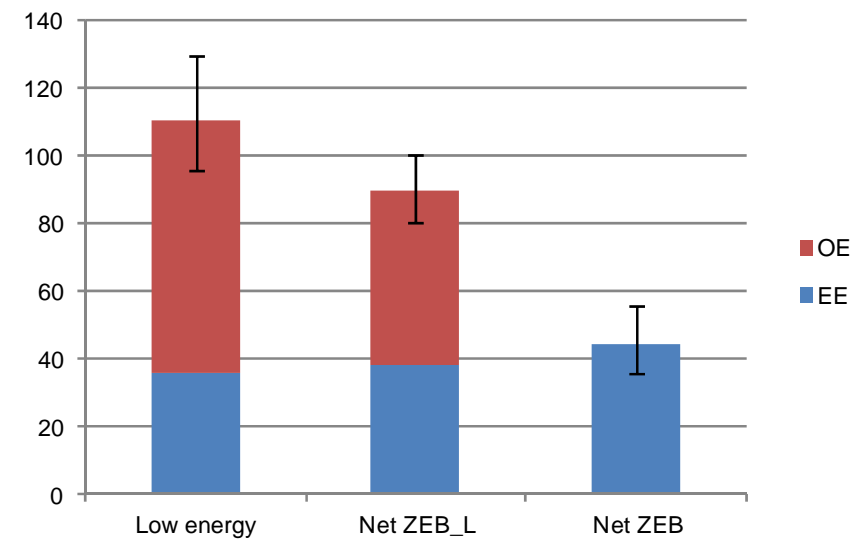

Fig. 11 Mean values of embodied energy (EE), operating energy (OE) and the variation of life cycle energy use (non-renewable primary energy), comparing three different building standards. 


\section{Conclusions}

Since the oil crisis in the 1970s, efforts have been made to reduce energy use in buildings to reduce the oil dependency. Today, reduction of energy use in buildings is also seen as an important strategy for climate mitigation. As the operational energy (OE) is reduced, the relative share of embodied energy (EE) increases.

Worldwide, extensive work has been carried out or is in progress to identify and calculate the environmental impact from construction materials or assemblies. However, a mandatory national requirement for buildings is unlikely to be seen within the next few years. This is largely due to that it requires a large effort to collect, calculate and analyze the environmental impact of different materials. Furthermore, there is no standardized approach for data collection.

In the review of previous studies, five parameters have been identified which vary between the different studies and thus may influence the outcome; metric of evaluation, assumed lifespan, boundary conditions, age of data and the origin of database. In order to increase transparency and allow for comparison between different studies, these parameters should always be clearly stated. In the review, it is possible to distinguish favoured choices within two of the parameters; life-span and metric of evaluation. The most used life span is 50 years and most studies choose consistently to apply primary energy for the LCE analysis.

The literature review shows that methods for calculating life cycle energy use are far from standardized. Today, it is therefore not suitable to try to include EE in a Net ZEB balance. However, it may be suitable to have as an additional/complementing requirement as defined within the Minergie-A requirements. To further facilitate the interpretation, clarification of results and increased transparency of analysis, the guidelines given in EN ISO 14040 [78] and EN ISO 14044 [79] may be followed.

Despite differences in different studies, the compilation shows that the previously found linear relationship between OE and LCE $[19,20]$ remains when the step is taken towards the Net ZEB balance.

Taking the step from Net ZEB $\mathrm{L}_{\mathrm{L}}$ to Net ZEB by increasing the use of solar energy roughly doubles the needed kWp of PV panels and more than doubles the area of solar thermal collectors. It is therefore imperative that all possible and cost efficient energy efficiency measures are applied in order to enable reaching the Net ZEB balance, especially in larger building where the relative areas suitable for PV panels and solar thermal collectors in relation to the heated area decreases. The analysis of EPT and NER for solar energy options shows that electricity from PV panels should primarily be used to replace electricity, not transformed and used for space heating or hot water heating.

The detailed analysis of the 11 Minergie-A buildings show that roughly $45 \%$ of energy demand is due to plug loads and lighting and $35 \%$ is embodied energy. The remaining energy loads are energy for heating, hot water and HVAC systems. The embodied energy is roughly to $60 \%$ due to structural elements, $20 \%$ due to HVAC systems and $20 \%$ due to ST collectors and PV.

The embodied energy increases slightly when taking the step from a low-energy building towards Net ZEB balance. However, the energy savings achieved related to building 
operation OE exceeds, with great margin, the increased embodied energy. The overall assessment shows that the life cycle energy use of a Net ZEB is about $60 \%$ lower compared with the life cycle energy use of a low energy building/Passive House. From a life cycle energy perspective, the Net ZEB is preferable over a low energy building.

Today, structural elements hold the largest share of embodied energy in buildings.

Therefore, a first step of implementing analysis of embodied energy could focus on structural elements. Technical systems that reduce the operating energy use, e.g. solar thermal collectors, PV panels and heat pumps, if properly designed; always reduce the operating energy use more than the increase of the embodied energy incorporated in the technical system.

The embodied energy has decreased slightly over time, indicating that the construction of buildings and technical systems in general has become more efficient over time. However, the relative share of embodied energy of the total life cycle energy is increasing. Increased use and acceptance of LCE analysis as an important parameter in the design of buildings may in a near future lead to design decisions not only based on energy savings related to operating energy. Thus, in new construction, choosing insulation material with low EE instead of increasing the amount of insulation in an already well-insulated construction may be a decision in a not so distant future. 


\section{Acknowledgements}

This research has been largely developed in the context of the joint IEA SHC

Task40/ECBCS Annex52: Towards Net Zero Energy Solar Buildings. The authors wish to thank all the national experts who have contributed.

This work is partly study is funded by The Development Fund of the Swedish Construction Industry (SBUF) and Skanska Sverige AB as part of the project; Klimatskal 2019, partly funded by the Swiss Federal Office of Energy (SFOF) as a part of the Swiss participation at the IEA project. 


\section{References}

[1] SHC Task40/ECBCS Annex52 IEA, Net Zero energy Buildings database, http://iea40.buildinggreen.com/index.cfm, Accessed September 10 2011.

[2] A. Lenoir, F. Garde, E. Wurtz, Zero Energy Buildings in France: Overview and Feedback in: ASHRAE Annual Conference 2011, ASHRAE, Montreal, 2011, pp. 13.

[3] E. Musall, T. Weiss, K. Voss, A. Lenoir, M. Donn, S. Cory, F. Garde, Net Zero Energy Solar Buildings: An Overview and Analysis on Worldwide Building Projects, in: Eurosun Conference 2010, Graz, 2010, pp. 9.

[4] K. Voss, E. Musall, Net zero energy buildings - International projects of carbon neutrality in building, Birkhauser Verlag, Basel, 2011.

[5] Fachinformationszentrum, Net zero-energy buildings - Map of international projects, http://www.enob.info/en/net-zero-energy-buildings/map/, Accessed April $5^{\text {th }} 2012$.

[6] U.S. Departement of Energy, High Performance Buildings Database, http://eere.buildinggreen.com/index.cfm, Accessed September $10^{\text {th }} 2011$.

[7] A.J. Marszal, P. Heiselberg, J.S. Bourrelle, E. Musall, K. Voss, I. Sartori, A. Napolitano, Zero Energy Building - A review of definitions and calculation methodologies, Energy and Buildings, 43 (4) (2011) 971-979.

[8] I. Sartori, A. Napolitano, A.J. Marszal, S. Pless, P. Torcellini, K. Voss, Criteria for Definition of Net Zero Energy Buildings, in: Eurosun Conference 2010, Graz, 2010.

[9] K. Voss, E. Musall, M. Lichtmeß, From Low-Energy to Net Zero-Energy Buildigns: Status and Perspectives, Journal of Green Building, 6 (1) (2011) 12.

[10] K. Voss, I. Sartori, A. Napolitano, S. Geier, H. Gonzalves, M. Hall, P. Heiselberg, J. Widén, J.A. Candanedo, E. Musall, B. Karlsson, P. Torcellini, Load Matching and Grid Interaction of Net Zero Energy Buildings, in: Eurosun Conference 2010, Graz, 2010, pp. 8.

[11] I. Sartori, A. Napolitano, K. Voss, Net zero energy buildings: A consistent definition framework, Energy and Buildings, 48 (0) (2012) 220-232.

[12] E. Musall, K. Voss, The Passive House Concept as Suitable Basis towards Net Zero Energy Buildings, in: 16th International Passive House Conference 2012, Hannover, 2012, pp. 6.

[13] U. Janson, Passive houses in Sweden - From design to evaluation of four demonstration projects, Doctoral thesis, Department of Architecture and Built Environment, Lund University, 2010.

[14] W. Feist, Passivhaus Institut 2011, What is a Passive House?, http://www.passiv.de/07 eng/index e.html, Accessed August 10 2011.

[15] Passive-House-Institute-US, What is a Passive House?, http://www.passivehouse.us/passiveHouse/PassiveHouselnfo.html, Accessed August $11^{\text {th }}$ 2011.

[16] K. Adalberth, Energy use during the life cycle of single-unit dwellings: Examples, Building and Environment, 32 (4) (1997) 321-329.

[17] K. Adalberth, Energy use in Multi-Family Dwellings during their Life Cycle, Docotral thesis, Lund University, 1999.

[18] B.N. Winther, A.G. Hestnes, Solar Versus Green: The Analysis of a Norwegian Row House, Solar Energy, 66 (6) (1999) 387-393.

[19] I. Sartori, A.G. Hestnes, Energy use in the life cycle of conventional and low-energy buildings: A review article, Energy and Buildings, 39 (3) (2007) 249-257. 
[20] T. Ramesh, R. Prakash, K.K. Shukla, Life cycle energy analysis of buildings: An overview, Energy and Buildings, 42 (10) (2010) 1592-1600.

[21] G.A. Blengini, T. Di Carlo, The changing role of life cycle phases, subsystems and materials in the LCA of low energy buildings, Energy and Buildings, 42 (6) (2010) 869-880.

[22] W. Feist, Life-cycle energy balances compared: low-energy house, passive house, selfsufficient house, in: International Symposium of CIB, 1997, pp. 999.

[23] B. Brunklaus, C. Thormark, H. Baumann, Illustrating limitations of energy studies of buildings with LCA and actor analysis, Building Research \& Information, 38 (3) (2010) 265279.

[24] J. Kneifel, Life-cycle carbon and cost analysis of energy efficiency measures in new commercial buildings, Energy and Buildings, 42 (3) (2010) 333-340.

[25] Swedish Standards Institute, Energy performance of buildings - Overall energy use and definition of energy ratings, Stockholm, 2008.

[26] MINERGIE®, http://www.minergie.ch/, Accessed September 20 2011.

[27] MINERGIE ${ }$, Reglement zur Nutzung des Produktes MINERGIE-A® der Qualitätsmarke MINERGIE®, in, Association MINERGIE®, 2011, pp. 17.

[28] Schweizer Ingenieur-und Architektenverein, SIA Merkblatt 380/1: Thermische Energie im Hochbau, Zürich, 2009.

[29] Holligerconsult, Bauteilkatalog 2011, http://www.bauteilkatalog.ch/ch/de/Bauteilkatalog.asp, Accessed September 10 2011.

[30] Minergie database, Minergie Agentur, CH-4132 Muttenz, 2011.

[31] Schweizer Ingenieur-und Architektenverein, SIA Merkblatt 2031: Energieausweis für Gebäude, Zürich, 2009.

[32] S. Junnila, A. Horvath, A.A. Guggemos, Life-Cycle Assessment of Office Buildings in Europe and the United States Journal of Infrastructure Systems, 12 (10) (2006) 7.

[33] D Carls, Bewertung und Optimierung von ökonomischen und ökologischen Bauwerkslebenszyklen am Beispiel BOB - Balanced Office Building, Master thesis, Fachbereich Architektur, Bergische Universität Wuppertal, 2007.

[34] D Kugel, Life cycle analyses as an economical and ecological savings potential in building planning and management, Bauphysik und technische Gebäudeausrüstung, University Wuppertal, 2007.

[35] CIRCE, ENSLIC BUILDING - Energy Saving through Promotion of Life Cycle Assessment in Buildings http://circe.cps.unizar.es/enslic/texto/d 4-2-circe.pdf Accessed April $10^{\text {th }} 2012$.

[36] Schweizer Solarpreis 2007, Marché international support office, http://www.solaragentur.ch/dokumente//M-07-10-16\%20Marche\%20International.pdf, Accessed April $10^{\text {th }} 2012$.

[37] Swiss Federal Institute of Aquatic Science and Technology, Forum Chriesbach - Energy, http://www.eawag.ch/about/nachhaltig/fc/energie/index EN, Accessed April $8^{\text {th }} 2012$.

[38] C. Scheuer, G.A. Keoleian, P. Reppe, Life cycle energy and environmental performance of a new university building: modeling challenges and design implications, Energy and Buildings, 35 (10) (2003) 1049-1064.

[39] S.F. Pullen, Energy used in the Construction and Operation of Houses, Architectural Science Review, 43 (2) (2000) 87-94. 
[40] Victoria Building commission, Energy Impacts of different house types in Victoria, http://www.buildingcommission.com.au/resources/documents/EE FactSheet FINAL 18June 06.pdf, Accesed September $12^{\text {th }} 2011$.

[41] G. Beccali, M. Cellura, F. Ardente, M. Fontana, S. Longo, Energy and environmental analysis of a mono-familiar Mediterranean house, in: World Sustainable Building Conference - SB08, Melbourne, 2008, pp. 8.

[42] Plataforma Arquitectura, LIMA House, http://www. plataformaarquitectura.cl/2010/11/12/lima-low-impact-mediterranean-architecturesaas/, Accessed April 10 2012.

[43] G.A. Keoleian, S. Blanchard, P. Reppe, Life-Cycle Energy, Costs, and Strategies for Improving a Single-Family House, Journal of Industrial Ecology, 4 (2) (2001) 22.

[44] N. Villa, E.D. Angelis, G. Iannaccone, L. Zampori, G. Dotelli, Life Cycle Assessment (LCA) of buildings applied on an Italian context, in: CleanTech for Sustainable Buildings From Nano to Urban Scale, Lausanne, 2011, pp. 6.

[45] M. Leckner, R. Zmeureanu, Life cycle cost and energy analysis of a Net Zero Energy House with solar combisystem, Applied Energy, 88 (1) (2011) 232-241.

[46] M.K. Dixit, J.L. Fernández-Solís, S. Lavy, C.H. Culp, Identification of parameters for embodied energy measurement: A literature review, Energy and Buildings, 42 (8) (2010) 1238-1247.

[47] ASHRAE, 189.1-2009: Standard for the Design of High-Performance Green buildings Except Low-Rise Residential Buildings, ASHRAE, 2009, pp. 126.

[48] Schweizer Ingenieur-und Architektenverein, SIA Merkblatt 2032: Graue Energie, Zürich, 2010.

[49] Schweizer Ingenieur-und Architektenverein, SIA Merkblatt 2040: Effizienzpfad Energie, Zürich, 2011.

[50] Istituto per l'innovazione e trasparenza degli appalti e la compatibilità ambientale, Protocollo ITACA 2011, http://www.itaca.org/, Accessed September 11 2011.

[51] US Green Building Council, LEED - Leadership in Energy and Environmental Design, http://www.usgbc.orgl, Accessed September $11^{\text {th }} 2011$.

[52] BRE Global, BREEAM, Building Research Establishment Environmental Assessment Method 2010-2012, http://www.breeam.org/, Accessed September 11 2011 .

[53] Bundesministeriums für Land- und Forstwirtschaft - Umwelt und Wasserwirtschaft, klima:aktiv haus, http://www.klimaaktiv.at/, Accessed September $11^{\text {th }} 2011$.

[54] Agenzia CasaClima, Klima Haus - CasaClima, http://www.agenziacasaclima.it, Accessed September $11^{\text {th }} 2011$.

[55] Green Building Council of Australia, Green Star, http://www.gbca.org.aul, Accessed September $11^{\text {th }} 2011$.

[56] Deutsche Gesellschaft für Nachhaltiges Bauen, DGNB Certificate, http://www.dgnb.de, Accessed September $11^{\text {th }} 2011$.

[57] Association pour la Haute Qualité Environnementale, Haute qualité environnementale, http://assohqe.org/hqel, Accessed September $11^{\text {th }} 2011$.

[58] Japan Sustainable Building Consortium, CASBEE, www.ibec.or.jp, Accessed September $11^{\text {th }} 2011$.

[59] Swiss Centre for Life Cycle Inventories, Ecolnvent, http://www.ecoinvent.org/database/, Accessed September $12^{\text {th }} 2011$. 
[60] Öko-Institut \& Gesamthochschule Kassel, GEMIS, http://www.gemis.de, Accessed September $12^{\text {th }} 2011$.

[61] IBO - Österreichisches Institut für Bauen und Ökologie entwickelt, IBO

Referenzdatenbank für Baustoffe, http://www.ibo.at, Accessed September $12^{\text {th }} 2011$.

[62] Ecospecifier Pty Ltd, Ecospecifier, http://www.ecospecifier.com.aul, Accessed September $12^{\text {th }} 2011$.

[63] U.S. Department of Energy, U.S. Life Cycle Inventory Database, http://www.nrel.gov/lci/, Accessed December $10^{\text {th }} 2011$.

[64] G. Hammond, C. Jones, F. Lowrie, P. Tse, The Inventory of Carbon and Energy (ICE), University of Bath with BSRIA, iCAT, 2010.

[65] German Ministry for Transport, Building and Urban Development, Ökobau.dat, http://www.nachhaltigesbauen.de/baustoff-und-gebaeudedaten/oekobaudat.html, Accessed September $12^{\text {th }} 2011$.

[66] Athena Institute, ATHENA® EcoCalculator for Assemblies, http://www.athenasmi.org/our-software-data/ecocalculatorl, Accessed November $12^{\text {th }} 2012$.

[67] NIST Building and Fire Research Laboratory, BEES - Building for Environmental and Economic Sustainability, http://www.nist.gov/el/economics/BEESSoftware.cfm/, Accessed September $12^{\text {th }} 2011$.

[68] WEKA MEDIA GmbH \& Co. KG, LEGEP-Ökobilanz, http://www.legep-software.de/, Accessed February $13^{\text {th }} 2012$.

[69] J.R.C. European Commission, Institute for Prospective Technological Studies, EU Ecolabel and Green Public Procurement for Buildings, http://susproc.jrc.ec.europa.eu/buildings/, Accessed December 10 2011.

[70] Institute for Environment and Sustainability, Life Cycle Thinking and Assesement, http://lct.jrc.ec.europa.eul, Accessed February $13^{\text {th }} 2012$.

[71] M. Suzuki, T. Oka, Estimation of life cycle energy consumption and CO2 emission of office buildings in Japan, Energy and Buildings, 28 (1) (1998) 33-41.

[72] R.J. Cole, P.C. Kernan, Life-cycle energy use in office buildings, Building and Environment, 31 (4) (1996) 307-317.

[73] L. Gustavsson, A. Joelsson, Life cycle primary energy analysis of residential buildings, Energy and Buildings, 42 (2) (2010) 210-220.

[74] M. Hall, B. Berggren, Embodied Energy of Net Zero Energy Buildings, in: 16th International Passive House Conference 2012, Hannover, 2012, pp. 2.

[75] A. Dodoo, L. Gustavsson, R. Sathre, Life Cycle Primary Energy Analysis Of Conventional And Passive House Buildings, in: World Sustainable Building Conference, Helsinki, 2011, pp. 8.

[76] P. Hernandez, P. Kenny, Development of a methodology for life cycle building energy ratings, Energy Policy, 39 (6) (2011) 3779-3788.

[77] E. Alsema, M.d. WildScholten, Reduction of environmental impacts in crystalline silicon photovoltaic technology: an analysis of driving forces and opportunities, in: Materials Research Society Fall 2007 Symposium, Boston, 2007, pp. 10.

[78] Swedish Standards Institute, Environmental management - Life cycle assessment Principles and framework (ISO 14040:2006), Stockholm, 2006.

[79] Swedish Standards Institute, Environmental management - Life cycle assessment Requirements and guidelines (ISO 14044:2006), stockholm, 2006. 


\section{Appendix A}

Table A. 1 Summary of gathered non-residential case studies with LCE-analysis (Primary energy)

\begin{tabular}{rrrrrrr}
\hline $\begin{array}{l}\text { Case } \\
\text { study }\end{array}$ & $\begin{array}{l}\text { Size } \\
{\left[\mathrm{m}^{2}\right]}\end{array}$ & Lifespan & $\begin{array}{l}\mathrm{EE} \\
{\left[\mathrm{kWh} / \mathrm{m}^{2} \mathrm{a}\right]}\end{array}$ & $\begin{array}{l}\mathrm{OE} \\
{\left[\mathrm{kWh} / \mathrm{m}^{2} \mathrm{a}\right]}\end{array}$ & $\begin{array}{l}\mathrm{LCE} \\
{\left[\mathrm{kWh} / \mathrm{m}^{2} \mathrm{a}\right]}\end{array}$ & Reference \\
\hline 1 & 4400 & 50 & 38 & 258 & 296 & {$[32]$} \\
2 & 4400 & 50 & 78 & 376 & 453 & {$[32]$} \\
3 & 2151 & 80 & 30 & 70 & 100 & {$[33]$} \\
4 & 4719 & 80 & 51 & 143 & 194 & {$[34]$} \\
5 & 1700 & 50 & 67 & 56 & 123 & {$[35]$} \\
6 & 1516 & 50 & 48 & 67 & 114 & {$[4,36]$} \\
7 & 11170 & 38 & 29 & 50 & 79 & {$[37]$} \\
8 & 7300 & 75 & 28 & 1142 & 1170 & {$[38]$} \\
\hline
\end{tabular}


Table A.2 Summary of gathered residential case studies with LCE-analysis (Primary energy)

\begin{tabular}{|c|c|c|c|c|c|c|}
\hline $\begin{array}{l}\text { Case } \\
\text { study }\end{array}$ & $\begin{array}{l}\text { Size } \\
{\left[\mathrm{m}^{2}\right]}\end{array}$ & $\begin{array}{l}\text { Lifespa } \\
\mathrm{n}\end{array}$ & $\begin{array}{l}\mathrm{EE} \\
{\left[\mathrm{kWh} / \mathrm{m}^{2} \mathrm{a}\right]}\end{array}$ & $\begin{array}{l}\mathrm{OE} \\
{\left[\mathrm{kWh} / \mathrm{m}^{2} \mathrm{a}\right]}\end{array}$ & $\begin{array}{l}\mathrm{LCE} \\
{\left[\mathrm{kWh} / \mathrm{m}^{2} \mathrm{a}\right]}\end{array}$ & Reference \\
\hline 9 & 236 & 50 & 34 & 206 & 240 & [39] \\
\hline 10 & 91 & 50 & 57 & 208 & 265 & [39] \\
\hline 11 & 135 & 50 & 39 & 317 & 356 & [39] \\
\hline 12 & 155 & 50 & 52 & 310 & 362 & [39] \\
\hline 13 & 132 & 50 & 58 & 236 & 294 & [39] \\
\hline 14 & 163 & 50 & 46 & 172 & 218 & [39] \\
\hline 15 & 120 & 50 & 55 & 255 & 309 & [39] \\
\hline 16 & 140 & 50 & 46 & 403 & 449 & [39] \\
\hline 17 & 239 & 50 & 54 & 195 & 250 & [39] \\
\hline 18 & 211 & 50 & 66 & 187 & 252 & [39] \\
\hline 19 & 140 & 50 & 36 & 185 & 221 & [39] \\
\hline 20 & 130 & 50 & 61 & 192 & 253 & [39] \\
\hline 21 & 154 & 50 & 41 & 211 & 252 & [39] \\
\hline 22 & 120 & 50 & 55 & 322 & 377 & [39] \\
\hline 23 & 147 & 50 & 63 & 168 & 231 & [39] \\
\hline 24 & 170 & 50 & 56 & 188 & 244 & [39] \\
\hline 25 & 120 & 50 & 91 & 241 & 332 & [39] \\
\hline 26 & 320 & 50 & 47 & 200 & 247 & [39] \\
\hline 27 & 121 & 50 & 48 & 305 & 353 & [39] \\
\hline 28 & 164 & 50 & 61 & 327 & 388 & [39] \\
\hline 29 & 122 & 50 & 61 & 189 & 250 & [39] \\
\hline 30 & 305 & 50 & 40 & 111 & 151 & [39] \\
\hline 31 & 168 & 50 & 52 & 202 & 254 & [39] \\
\hline 32 & 192 & 50 & 60 & 166 & 227 & [39] \\
\hline 33 & 124 & 50 & 95 & 417 & 512 & [39] \\
\hline 34 & 200 & 50 & 20 & 44 & 64 & [40] \\
\hline 35 & 200 & 50 & 17 & 46 & 63 & [40] \\
\hline 36 & 200 & 50 & 16 & 51 & 66 & [40] \\
\hline 37 & 200 & 50 & 19 & 49 & 67 & [40] \\
\hline 38 & 200 & 50 & 14 & 77 & 91 & [40] \\
\hline 39 & 108 & 50 & 61 & 163 & 223 & [41] \\
\hline 40 & 45 & 60 & 26 & 15 & 40 & [42] \\
\hline 41 & 228 & 50 & 37 & 353 & 390 & [43] \\
\hline 42 & 228 & 50 & 41 & 115 & 157 & [43] \\
\hline 43 & 1404 & 50 & 23 & 217 & 240 & [44] \\
\hline
\end{tabular}




\begin{tabular}{|c|c|c|c|c|c|c|}
\hline 44 & 1404 & 50 & 54 & 217 & 271 & [44] \\
\hline 45 & 1404 & 50 & 64 & 217 & 281 & [44] \\
\hline 46 & 1404 & 50 & 16 & 228 & 245 & [44] \\
\hline 47 & 1404 & 50 & 20 & 228 & 248 & [44] \\
\hline 48 & 1404 & 50 & 26 & 228 & 255 & [44] \\
\hline 49 & 1404 & 50 & 20 & 227 & 246 & [44] \\
\hline 50 & 1404 & 50 & 23 & 227 & 250 & [44] \\
\hline 51 & 1404 & 50 & 23 & 227 & 250 & [44] \\
\hline 52 & 1453 & 50 & 31 & 131 & 163 & [44] \\
\hline 53 & 1453 & 50 & 59 & 131 & 190 & [44] \\
\hline 54 & 1453 & 50 & 51 & 131 & 182 & [44] \\
\hline 55 & 1484 & 50 & 33 & 125 & 158 & [44] \\
\hline 56 & 1484 & 50 & 48 & 125 & 172 & [44] \\
\hline 57 & 1484 & 50 & 38 & 125 & 163 & [44] \\
\hline 58 & 982 & 50 & 80 & 62 & 143 & [44] \\
\hline 59 & 96 & 50 & 18 & 239 & 258 & [45] \\
\hline 60 & 96 & 50 & 19 & 184 & 203 & [45] \\
\hline 61 & 96 & 50 & 20 & 155 & 175 & [45] \\
\hline 62 & 96 & 50 & 23 & 95 & 119 & [45] \\
\hline 63 & 96 & 50 & 25 & 78 & 102 & [45] \\
\hline 64 & 96 & 50 & 26 & 66 & 93 & [45] \\
\hline 65 & 96 & 50 & 27 & 65 & 92 & [45] \\
\hline 66 & 96 & 50 & 29 & 55 & 84 & [45] \\
\hline 67 & 96 & 50 & 31 & 50 & 81 & [45] \\
\hline 68 & 96 & 50 & 35 & 31 & 66 & [45] \\
\hline 43 & 96 & 50 & 39 & 12 & 51 & [45] \\
\hline 70 & 96 & 50 & 44 & -7 & 37 & [45] \\
\hline
\end{tabular}




\section{Appendix B}

Table B.1 Effect on $\mathrm{EE}_{\mathrm{T}}$ and $\mathrm{EE}$ in Minergie-A case studies due to PV and ST collectors

\begin{tabular}{|c|c|c|c|c|c|c|c|c|c|}
\hline \multirow[t]{2}{*}{$\begin{array}{l}\text { Case } \\
\text { study }\end{array}$} & \multicolumn{3}{|c|}{$\begin{array}{l}\Delta \mathrm{EE}_{\mathrm{T}}{ }^{*} \\
{\left[\mathrm{kWh} / \mathrm{m}^{2} \text { heated area }\right]}\end{array}$} & \multicolumn{3}{|c|}{$\begin{array}{l}\Delta \mathrm{EE} * \\
{\left[\mathrm{kWh} / \mathrm{a}, \mathrm{m}^{2} \text { heated area] }\right.}\end{array}$} & \multicolumn{3}{|c|}{$\begin{array}{l}-\Delta O E^{\star \star} \\
{\left[k W h / a, m^{2} \text { heated area] }\right.}\end{array}$} \\
\hline & PV & STC & $\mathrm{HP}$ & PV & STC & $\mathrm{HP}$ & PV & STC & $\mathrm{HP}$ \\
\hline 71 & 341 & 64 & & 11.4 & 3.2 & & 37.5 & 18.3 & \\
\hline 72 & 153 & 33 & & 5.1 & 1.6 & & 15.9 & 10.2 & \\
\hline 73 & 151 & 28 & 29 & 5.0 & 1.4 & 1.0 & 14.6 & 7.8 & 26.8 \\
\hline 74 & 313 & 63 & & 10.4 & 3.2 & & 33.7 & 30.6 & \\
\hline 75 & 198 & & & 6.6 & & & 24.1 & & \\
\hline 76 & 162 & 32 & 29 & 5.4 & 1.6 & 1.0 & 15.7 & 11.7 & 36.3 \\
\hline 77 & 270 & 62 & & 9.0 & 3.1 & & 32.9 & 25.5 & \\
\hline 78 & 161 & 32 & & 5.4 & 1.6 & & 19.6 & 8.7 & \\
\hline 79 & 241 & 28 & & 8.0 & 1.4 & & 26.2 & 9.7 & \\
\hline 80 & 160 & & 29 & 5.3 & & 1.0 & 18.2 & & 34.7 \\
\hline 81 & 118 & & 29 & 3.9 & & 1.0 & 12.9 & & 35.5 \\
\hline
\end{tabular}

* Non-renewable primary energy

** Un-weighted energy. Differences in primary energy are calculated using factors presented in Table 2 